\title{
Book Reviews | Rezensionen
}

\author{
Becker, Joachim/Weissenbacher, Rudy (2007): Dollarization, Euroization and Financial \\ Instability. Central and Eastern European Countries between Stagnation and Financial \\ Crisis?, Marburg (280 pages, Metropolis, ISBN: 978-3-895I8-630-I)
}

The process of Eastern enlargement has caused great attention within academia as well as on the policy making level as it differs a lot from former EU enlargements in the sense that these new member states are structurally different in terms of both their economies and their historical, political and social dynamics. Hence, the analysis of the process of »structural adjustment « in terms of the integration of the new members to EU from 2004 on, which to a large extent consists of drastic changes in macroeconomic policy-making for the objective of joining the European Monetary Union - »euroization « -, has been of major interest.

The analyses in Dollarization, Euroization and Financial Instability - Central and Eastern European Countries between Stagnation and Financial Crisis? within this framework, develop a critical approach to the process of the EU-integration in Central and Eastern Europe (CEE). The book is divided into four main parts: „Uneven Development and Transformations in Europe«; »Implications of Foreign Direct Investments (FDI) in CEE«; »Current Account Deficits, Foreign Debt and Financial Crisis« and "Dilemmas of Euroization«, referring to the main issues covered in the articles.

The first part, in a way, aims to analyze the historical background of Central and Eastern Europe leading to EU membership. The article of Joze Mencinger argues that CEE countries seem to have gained nothing considerable although they have given up many attributes characterizing a country as an economic entity as a result of which they turned from countries to peripheral regions of the EU. The second article of Rudy Weissenbacher on Historical Considerations of Uneven Development in East Central Europe investigates the historical roots of peripheralization in the region from the fifth century onwards.

The second part specializes on foreign direct investment (FDI) flows to CEE countries. Jan Drahokoupil in his article refers to the similarities and differences in the Visegrad Four (V4) countries (Hungary, Poland, Czech Republic and Slovakia) as far as the transformation of state strategies from national capitalism in the early I990's to foreign-led growth in the late I990's is concerned. In the second article of this part, Joze Mencinger presents an econometric work measuring the impact of FDI's on the new member states. Analyzing the effect of FDI on the current account balance, he finds that the worsening of current account balances due to the investment account is accompanied by trade account deficits rather than surpluses in new member states.

The first article of the third part by Özlem Onaran looks at the possibility of a financial crisis in CEE countries. Given the rising current account deficit as a ratio of GDP, rising short-term foreign debt as a ratio of total debt and rapid overvaluation of the national 
currencies, Onaran concludes that there is a strong tendency towards a financial crisis, and its implications are to be seen as the global markets go through shrinkage in liquidity. The second article by Carolina Villalba and Paola Visca is a comparative work on the neo-liberal exchange rate stabilization and debt restructuring programs in Argentina, Brazil and Uruguay in the early 1990's which resulted in severe economic crises during that as well as in the following decade in all the three countries. The article, in that sense, draws parallels with the contemporary dynamics in the CEE countries.

The fourth and last part of the book consists of four articles dealing with the euroization phenomenon in a more specific way. The first article written by Bela Galgoczi discusses the potential impacts of the adoption of the euro for the CEE countries. What Galgoczi basically indicates is the fact that applying the same Maastricht and Stability and Growth Pact criteria, which are applied to other EU members, to CEE countries is neither economically rational nor sustainable, since CEE countries are in the period of "catching up « to Western Europe. In the second article, Petr Gocev analyzes the debate among economists on the Eurozone accession of the Czech Republic. Parallel to this, the third article, written by Laszlo Andor, investigates the Hungarian Eurozone accession case. The problem the author points out is similar to the one of Galgoczi: CEE countries, especially the Visegrad Four countries which constitute 90 percent of the EU-8, are still in the phase of catchingup, i.e. large scale capital inflows and export-led economic recovery. The implementation of the Maastricht criteria, however, subordinates real convergence to monetary convergence in these countries. The final article of the book, by Joachim Becker, compares the formal as well as informal dollarization in Latin America that started in the 1970's with the formal as well as informal euroization in Eastern Europe that started in the I990's. Becker indicates that pegging to a credible currency such as the euro or the dollar to build legitimacy in fighting high inflation subordinates economic policies to exchange rate stabilization and capital inflows which lead to high current account deficits eroding the competitiveness of productive sectors which ultimately result in huge devaluation and severe financial crisis. Becker argues that Latin American experiences, in particular, indicate that the result has always been severe financial crisis, given the huge impact of advanced dollarization. Hence, the article sends a serious "warning signal « to CEE countries in that sense. Another important point Becker makes is that even if there are different economic/political motivations behind euroization in different regions/countries of Europe, all territories commonly display a trade balance deficit that is not sustainable in the long-run.

As Joachim Becker and Rudy Weissenbacher, the two editors of the book, pointed out in the introductory part, the "euroization « processes in Central and Eastern Europe (CEE) which inevitably brought radical neo-liberal macroeconomic policies into the forefront have contributed to their financial vulnerability in forms of rising inflation, overvalued (hence unstable and unsustainable) exchange rates, a weakening of productive sectors, lowering growth, exacerbating debt structure and worsening current account deficits. The articles in the book successfully show the dynamics of this vicious cycle. Furthermore, the book develops analytically convincing country-specific analyses of the transition process- 
es related to the adoption of the euro by looking at the different social, economic and political dynamics as well as the related historical background in these countries. Finally, the book, again quite successfully, emphasizes the similarities between the dollarization experience in Latin American countries and the euroization experience in CEE, which can be seen as a warning signal to CEE as the dollarization in Latin America in the I99o's resulted in severe financial crises within a short period of time.

To conclude, Dollarization, Euroization and Financial Instability with its solid socio-economic and historical perspective, good structuring in terms of the subdivisions of the topic, rich analytical framework of the articles and a wide range of references to related literature, in my view, constitutes a valuable source for thinking, developing as well as applying alternative economic policies with regard to the Eastern enlargement of the European Union.

Berksoy Bilgin, University of York, UK

Arestis, Philip/Sawyer, Malcolm (eds.) (2006): A Handbook of Alternative Monetary Economics (524 pages, hardcover, Edward Elgar, ISBN I-84376-9I5-8)

'Monetary analysis« can be considered to be the distinguishing feature of modern PostKeynesian economics when it is compared to mainstream economics which follows real analysis by and large. According to Schumpeter (1954), in rreal analysis the equilibrium values of employment, distribution and growth can be determined without any reference to money or monetary variables. In 'monetary analysisı, however, monetary variables enter into economic theory at the very beginning and the real equilibrium cannot be determined without reference to money and monetary interest rates. Whereas in Post-Keynesian economics money, monetary and hence macroeconomic policies are neither neutral in the short nor in the long run, in mainstream Neoclassical, Neoclassical Synthesis, Monetarist, New Classical, Real Business Cycle, New Keynesian and New Consensus models this neutrality is supposed at least for the long run, in New Classical and Real Business Cycle models even for the short run. Therefore, the Handbook of Alternative Monetary Economics edited by Philip Arestis and Malcolm Sawyer addresses the core of modern Post-Keynesian economics. It covers major contributions to money and finance in heterodox economics in general, and in Post-Keynesian economics in particular. Two major themes are running through most of the 29 chapters authored by well known experts in their fields: I. Money is credit money created by the financial system. The quantity of money is endogenous to the economic process and not under direct control of the monetary authorities. 2. The financial system is of utmost importance for growth and economic development, but is subject to volatility, instability and crisis.

Having gone through the contributions to this handbook, I would have preferred them being grouped into three sections. The editors, however, have abstained from this and have also chosen an order of chapters which makes it sometimes difficult to see the inter- 
relationships between the different aspects of heterodox approaches to money and finance addressed in this handbook.

A first part of contributions covers chapters on the fundamentals of money, interest, credit and the macroeconomy. The origin of money is addressed by Eric Tymoigne and Randall Wray, and different approaches to the understanding of money and interest are presented: Chartalism and the tax-driven approach to money by Pavlina Tcherneva, the property explanation of interest and money by Gunnar Heinsohn and Otto Steiger, and Keynesian uncertainty and money by Giuseppe Fontana. The famous accomodationists versus structuralists debate on the understanding of the relationship between the rate of interest and the volume of money and credit is touched in four contributions: Marc Lavoie presents the accommodationist view on endogenous money, Sheila Dow the structuralist view, Jörg Bibow elaborates on liquidity preference theory and Peter Howells discusses empirical evidence. Endogeneity of money and credit are best understood with the help of a model of a monetary circuit. Three such approaches are covered: the French circuit theory by Claude Gnos, the Italian circuitist approach by Riccardo Realfonzo and the theory of money emissions by Sergio Rossi. Finally, the contributions on the founding fathers of monetary theory also fall into this first part: Paul Davidson elaborates on Keynes, Elisabetta De Antoni on Minsky, Malcolm Sawyer on Kalecki and Suzanne de Brunhoff and Duncan Foley on Marx.

A second part of contributions deals with monetary policy issues. John Smithin in a chapter on the theory of interest rates argues that the interest rate should be seen as a distribution parameter under the control of the monetary authorities. Roy Rotheim deals with the role of credit rationing, now famous in New Keynesian economics. Greg Hannsgen gives a critical overview of the transmission mechanisms of monetary policy. The development of mainstream theory of monetary policies, from Friedman's expectations augmented Phillips curve and the natural rate of unemployment to the nowadays prevalent NAIRU, inflation targeting, rational expectations, credibility and central bank independence, is critically discussed by James Forder. Thomas Palley gives an account of monetary policy in an endogenous money economy, arguing in favour of an interest operating procedure targeting the minimum unemployment rate of inflation, which should be supplemented by asset based reserve requirements in order to cope with asset and debt bubble problems. Finally Michael Knittel, Susanne Sobczak and Peter Spahn discuss the role of the central bank as a lender of last resort.

A third part of contributions deals with issues of finance, growth and crises. Philip Arestis gives an overview on financial liberalisation and the relationship between finance and growth arguing that the orthodox view on the growth enhancing effects of financial liberalisation is far from convincing. Santonu Basu presents a detailed account of the role of banks in economic development of South Korea and India. Dorene Isenberg describes financial liberalisation in the US in a very detailed way without, however, deriving any implications with respect to growth and development. Banking and financial crises are discussed by Gary Dymski from a theoretical and a historical/empirical perspective. Ilene Grabel deals with the same issue but focuses on the developing world and discusses directions of reforms 
of the financial system as well. Matias Vernengo also takes a long-run historical view on money and inflation with a focus on episodes of hyperinflation and evaluates theoretical explanations. Finally, Mark Hayes elaborates on financial bubbles from a theoretical perspective, criticizing the efficient market hypothesis and developing a Keynesian perspective on the issue. Korkut Erturk gives a more in depth account of the development of the arguments in Keynes on speculation, liquidity preference and monetary circulation, from the Treatise on Money to the General Theory.

This handbook covers a wide variety of issues of money and finance from a heterodox perspective and it proves that very convincing work is going on beyond mainstream economics. However, although being already quite voluminous this handbook is missing chapters on money, distribution and capital accumulation and on the macroeconomic effects of financialisation. In both areas a lot of work has been done during the last decade and the integration of this work would have improved this handbook. Nonetheless, Arestis and Sawyer have done a marvellous job bringing together all these contributions, and I can highly recommend this handbook to students and researchers in the area of money, finance and macroeconomics.

Eckhard Hein, Macroeconomic Policy Institute (IMK), Hans Boeckler Foundation, Duesseldorf

\author{
Schürz, Martin/Weber, Beat (2008): Das Wissen vom Geld. Auf dem Weg zum \\ Finanzbildungsbürgertum, Graz (I3I Seiten, broschiert, Nausner \& Nausner, ISBN 978-3- \\ 90I402-I3-5)
}

Was die Autoren in dem vorgelegten Buch knapp und pointiert diskutieren, ist eine grundsätzliche ökonomische, soziale und politische Verschiebung im Umgang mit dem Geld unter dem verheißungsvollen Titel "Glück». Auf welche Art und Weise verändert der aus dem Staub der Geschichte wiederkehrende Diskurs über das Glück der Einzelnen als Voraussetzung einer individuellen Vermögensbildung die soziale Lebenswelt, welche »Narrative« führen zu einer Vereinzelung im sozialen Raum, sodass Fragen nach der Gerechtigkeit zugunsten individueller Verantwortungen ab-, wenn nicht im sozialen Unbewussten verdrängt werden? Das Buch ist demnach im besten und immer noch aufgeklärten Sinn kritisch.

Methodisch werden die Kritische Theorie und vor allem einige diskursive Fäden Michel Foucaults im Hinblick auf "Subjektivierungstechniken " (9I) oder einem "Dauerappell zur Selbstoptimierung "(I22) hervorgehoben. Das Glück als Gegenstand der Ökonomie ist demnach nicht harmlos oder offensichtlich. Es ist schlicht nicht einerlei, ob das Glück Ziel und Zweck (telos) einer Gemeinschaft ist, wie in den Schriften Aristoteles ersichtlich, aber nur, sofern vorweg auf Basis einer natürlichen oder ökonomischen Ungleichheit, Gleichheit, besondere und allgemeine Gerechtigkeit wirklich werden, oder ob das Glück der Einzelnen die Voraussetzung eines Gemeinwesens ist. Kants Ablehnung des utilitaristischen "Glücksdespotismus« ist ein verbindliches Richtmaß, wohin eine auf dem jeweiligen Glück 
fundierte Gesellschaft führen kann. Der utilitaristische Panoptismus - das Panopticon als disziplinierende Glücksmaschine - musste ja vorweg erst Individuen bilden, so dass diese ein konstantes ökonomisches Motiv hatten.

Die rezente "Glücksforschung (Kahneman/Layard) ist bemüht, einen das BIP ergänzenden Wohlstandsbegriff auf Basis individueller Zufriedenheit und jeweiligen Glücks einzubringen, wobei das Ergebnis durchwegs zweifelhaft ist: "Geld macht nicht glücklich und mit Geld kann man sich Glück nicht kaufen " (30). Die diskursiven Ergebnisse sind aber beträchtlich und verschieben die sozialen Gewichte: „Glück bzw. seine Voraussetzungen liegen dann nicht in der gemeinsam ausgehandelten Idee einer gerechteren Gesellschaft, sondern beim Individuum " (3I). Politik wird deshalb zunehmend "Para-Politik" (Slavoj Žižek), d.h. dass keine partikularen Forderungen im Namen einer möglichen Allgemeinheit mehr erhoben werden, sondern das je individuelle Glück der Einzelnen verwaltet wird. Dort, wo Gesellschaftspolitik und Ökonomik im Namen des jeweiligen Glücks intervenieren, schweigen die verallgemeinerbaren Vernunftansprüche der Einzelnen an ein gerechtes Gemeinwesen.

Die Autoren belegen diese rezente ökonomische Logik des Glücks anhand der Finanzialisierung: "Mittlerweilen spricht man in der Wirtschaftsforschung vom Phänomen der "Finanzialisierung", um den Prozess des Vordringens einer Finanzmarkt-Logik in immer weitere Bereiche von Wirtschaft, Politik und Alltag zu beschreiben.« (37). Allerorten ist aber zu bemerken, dass die Einzelnen - mit wenig Einkommen - wenig Interesse für eine private Altersvorsorge, allgemein für zukünftige Einkommensströme aufbringen. Deshalb werden von maßgebenden Institutionen wie OECD, G 8 oder nationalstaatlichen Anbietern Bildungsprogramme entworfen, sodass die Einzelnen in ihrer vermeintlichen Wahlfreiheit mehr Risikobereitschaft, Eigenverantwortung erkennen lassen, und sich deshalb über die angebotenen Finanzdienstleistungen bilden sollen. Kultur und Politik sollen demnach einer »Investmentkultur" (70) weichen: „Das gesellschaftliche Konstrukt der Eigentümergesellschaft ist auf die Formung neuer Subjekte ausgerichtet. Unternehmerisch denkende und handelnde Menschen sind das Bildungsziel (I2I).

Selbst die Rolle des Staates, als das vordergründig politisch Allgemeine schlechthin - setzt man das von Kant hervorgehobene "Weltbürgerliche« beiseite - ist nicht eine, die von der Bühne verschwindet: „Die Nutzung der Wahlfreiheit muss als ökonomisches Selbstmanagement gelernt werden. Der Staat zieht sich nicht aus der Gesellschaft zurück, sondern variiert seine Steuerungstechnik« (I2I). Die Bildung von Subjekten im Namen der Finanzialisierung geht zulasten eines Gemeinwesens im möglichen Zustand der Aufklärung: "Geht es nach der neoliberalen Denkrichtung, soll Reichtum vor den Umverteilungsansprüchen der Massen geschützt werden« (I22).

Insgesamt ist festzuhalten: Vor uns liegt ein wissenschaftliches Buch, das in guter ökonomischer Tradition, die Auswirkungen einer spezifischen ökonomischen Logik auf gesellschaftliche und politische Bewegungen analysiert, ohne einäugig - »cyclopisch" (Kant) - Fragen nach dem politisch gerechten Allgemeinen in prekärer Arbeitsteilung an andere Disziplinen zu delegieren. Dass der homo oeconomicus nicht nur ein methodisches Instrument 
ist, sondern bisweilen massiv Lebenswelten verändert, wurde von den Autoren verdienstvoll hervorgehoben. Ohne spekulative Geste, vielmehr mit größter Kenntnis der gegenwärtigen ökonomischen Forschungen sowie wirtschaftspolitischen Interventionen werden die diskursiven, mithin auch praktischen Veränderungen im sozialen Raum diskutiert. Dass nach den ökonomischen Analysen Fragen nach der Gerechtigkeit als Teilnahme aller am politischen Prozess aufgeworfen werden, liegt nicht jenseits der Ökonomik, sondern ist deren Bringschuld. Dass dies den Autoren mit luzider Diktion gelang, verdient allgemeinen Beifall.

Hermann Rauchenschwandtner, Wirtschaftsuniversität Wien

Görgens, Hartmut (2008): Sind die Löhne in Deutschland zu hoch? Zablen, Fakten, Argumente, 2. überarbeitete Auflage, Marburg (439 Seiten, gebunden, Metropolis Verlag, ISBN 978-3-895I8-662-2)

Bosch, Gerhard/Weinkopf, Claudia (Hg.) (2007): Arbeiten für wenig Geld. Niedriglohnbeschäftigung in Deutschland, Frankfurt (320 Seiten, broschiert, Campus Verlag, ISBN 978-3-593-38429-0)

Über kaum ein wirtschaftspolitisches Thema ist in der jüngsten Vergangenheit so intensiv gestritten worden wie über Höhe und Struktur der Löhne. Die große Mehrheit der an deutschen Hochschulen oder Wirtschaftsforschungsinstituten tätigen Ökonominnen und Ökonomen ist nach wie vor der Auffassung, dass der trotz Konjunkturaufschwungs immer noch bestehende beträchtliche Arbeitsplatzmangel vor allem auf allgemein zu hohe Löhne und eine zu geringe Lohnspreizung zurückzuführen sei. Insbesondere der Niedriglohnsektor, so die vielfach zu hörende These, müsse ausgebaut werden, solle in Deutschland jemals wieder Vollbeschäftigung erreicht werden.

Wer diesen neoklassisch geprägten Argumentationsmustern mit Fakten begegnen will, der kann auf zwei neuere Publikationen zurückgreifen. Hartmut Görgens beschäftigt sich in seinem binnen kurzer Frist schon in der zweiten Auflage erschienenen Buch mit der Frage, ob in Deutschland die Löhne tatsächlich zu hoch sind. Görgens, der als Leiter des Sachgebietes Konjunktur-, Wachstums- und Beschäftigungspolitik beim DGB-Bundesvorstand mit der Problematik der Lohnentwicklung 30 Jahre lang als Akteur befasst war, erläutert alle wichtigen Begriffe und Zusammenhänge zum Thema Lohn und Gewinn und trägt eine große Menge von zum Teil bis in die I97oer Jahre reichenden Zahlenreihen zum Thema zusammen. Allein schon durch dieses Zahlenmaterial hat das Buch einen hohen Gebrauchswert - egal, ob es um die Entwicklung der Brutto- oder Nettolöhne pro Stunde oder um die realen und nominalen Lohnstückkosten geht - Görgens dürfte keine wichtige Größe vergessen haben. Erfreulich ist, dass die jährlich aktualisierten Tabellen und Schaubilder auf der Internetseite des Verlags kostenlos zur Verfügung gestellt werden. 
Auf Basis seiner vor allem empirisch ausgerichteten Kritik zieht Görgens die neoklassische Argumentation überzeugend in Zweifel, in Deutschland seien Löhne und Lohnnebenkosten sowie Gewinnsteuern zu hoch und die Kapitalrentabilität zu niedrig. Als störend kann allerdings der häufig stark moralisierend-anklagende Tonfall empfunden werden, mit dem der Autor gegen den deutschen wirtschaftswissenschaftlichen Mainstream zu Felde zieht oder gewerkschaftsnahe Ökonomen auffordert, sich genauer mit bestimmten Sachverhalten wie etwa der exakten Ermittlung der Unternehmensgewinne auseinander zu setzen. Zudem hätte das Buch durch ein Kapitel gewonnen, in dem die Grundlagen der neoklassischen Verteilungstheorie erläutert und diese Theorie auch theorieimmanent kritisiert worden wäre - für letzteres böten insbesondere die in Deutschland fast überhaupt nicht rezipierten Ergebnisse der so genannten Cambridge-Kontroverse reichlich Material. Trotz dieser Mängel muss Görgens bescheinigt werden, dass er sich in Sind die Löhne in Deutschland zu hoch? fakten- und kenntnisreich mit den herrschenden verteilungspolitischen Vorstellungen auseinandersetzt und schlüssig herausarbeitet, dass die Probleme am deutschen Arbeitsmarkt nicht auf zu hohe Löhne zurückgeführt werden können.

Während Görgens sich ausführlich mit Lohnfragen im Allgemeinen befasst, behandelt der von Gerhard Bosch und Claudia Weinkopf herausgegebene Sammelband mit dem deutschen Niedriglohnsektor einen speziellen lohnpolitischen Komplex. Dabei dürfte Arbeiten für wenig Geld - Niedriglohnbeschäftigung in Deutschland die bis dato wohl umfangreichste Studie zu diesem Thema sein.

Nach einem ausführlichen Blick auf die Niedriglohnarbeit in Deutschland insgesamt werden fünf Branchen- und Betriebsfallstudien vorgestellt, und zwar für die Bereiche Call-Center, Einzelhandel, Ernährungsindustrie, Hotel und Krankenhaus. In allen untersuchten Branchen werden ein gestiegener Kostendruck und ein verschärfter Wettbewerb ausgemacht, der die Löhne erheblich unter Druck setzt. Die Ursachen hierfür sind teilweise ähnlich, zum Teil aber auch branchenspezifisch. Strategisch reagieren die Unternehmen hierauf mit Kostenreduktionen in Form von Lohnsenkungen und einer erhöhten Flexibilität - konkret wird dies insbesondere durch Outsourcing erreicht und eine verstärkte Nutzung von Minijobs. Der Zeitarbeit, die bei der Verbreitung von Niedriglohnbeschäftigung in Deutschland ebenfalls eine bedeutende Rolle spielt, kommt in den untersuchten Bereichen keine wesentliche Bedeutung zu.

Insgesamt liefert Arbeiten für wenig Geld eine Fülle von empirischen Befunden, die kennen muss, wer sich zu den Themen Niedriglohnsektor und Mindestlohn eine fundierte Meinung bilden will. Die aus ihren Befunden abgeleiteten Empfehlungen von Bosch und Weinkopf an die Politik sind im Übrigen eindeutig: sie plädieren für die Einführung von gesetzlichen Mindestlöhnen, und sie sehen erheblichen Handlungsbedarf bei den Regelungen von Zeitarbeit und Minijobs. 